\title{
NEOLIBERALISM OR
}

\section{REGULATORY CAPITALISM}

\author{
John Braithwaite
}

Occasional Paper 5

October 2005 
NEOLIBERALISM OR REGULATORY CAPITALISM

John Braithwaite

Regulatory Institutions Network Research School of Social Sciences Australian National University Canberra ACT 0200

ISBN 0-9756819-5-8 (online)

RegNet Occasional Paper No 5

October 2005 
(C) Regulatory Institutions Network, Research School of Social Sciences, Australian National University 2005

National Library of Australia

Cataloguing-in-Publication data:

Braithwaite, John, 1951- .

Neoliberalism or regulatory capitalism

ISBN 0-9756819-5-8 (online)

1. Capitalism. 2. Neoliberalism. 3. Globalisation.

I. Australian National University. Regulatory Institutions

Network. II. Title. (Series : RegNet occasional paper ; no. 5).

330.122

\section{Disclaimer}

This article has been written as part of a series of publications issued from the Regulatory Institutions Network. The views contained in this article are representative of the author only and not of the Australian National University or any funding partner. 


\section{REGNET OCCASIONAL PAPERS}

This series of occasional papers is designed to bring the research of the Regulatory Institutions Network to as wide an audience as possible and to promote discussion among researchers, academics and practitioners both nationally and internationally on regulation.

The peer-reviewed occasional papers are selected with three criteria in mind:

(1) to share knowledge, experience and preliminary findings from research projects;

(2) to provide an outlet for policy focused research and discussion papers; and

(3) to give ready access to previews of papers destined for publication in academic journals, edited collections, or research monographs. 


\begin{abstract}
Jacint Jordana and David Levi-Faur have provided systematic evidence that, since 1980, states have become rather more preoccupied with steering and less with rowing. Yet non-state regulation has grown even more rapidly, so it is not best to conceive of the era in which we live as one of the Regulatory State, but of Regulatory Capitalism. It is argued that Regulatory Capitalism is not about neoliberalism, indeed that those who think we are in an era of neoliberalism are mistaken. The corporatisation of the world is conceived as a product of regulation and the key driver of regulatory growth, indeed of state growth more generally. The reciprocal relationship between corporatisation and regulation creates a world in which there is more governance of all kinds.
\end{abstract}




\section{Neoliberalism or Regulatory Capitalism?}

John Braithwaite ${ }^{1}$

\section{Regulation and Governance}

States can be thought of as providing, distributing and regulating ${ }^{2}$. They bake cakes, slice them, and proffer pieces as inducements to steer events. Regulation is conceived as that large subset of governance that is about steering the flow of events, as opposed to providing and distributing. ${ }^{3}$ Of course when regulators regulate, they often steer the providing and distributing that regulated actors supply. Governance is a wider set of control activities than government. Students of the state noticed that government has shifted from "government of a unitary state to governance in and by networks" (Bevir and Rhodes 2001, 1; Rhodes 1997). But because the informal authority of networks in civil society not only supplements but also supplants the formal authority of government, Bevir, Rhodes and others in the networked governance tradition (notably Castells 1996) see it as important to study networked governance for its own sake, rather than as simply a supplement to government. This essay proceeds from the assumption that there has been a rise of networked governance, without considering the analyses of the likes of Castells, Rhodes and Bevir as to why this might have occurred.

We build on Jacint Jordana and David Levi-Faur's (2003, 2004) systematic evidence that, since 1980, states have become rather more preoccupied with the

\footnotetext{
${ }^{1}$ My thanks to Rod Rhodes, Peter Grabosky, Jennifer Woods, Susanne Karstedt, Adam Crawford, Clifford Shearing, Christine Parker and Peter Drahos for helpful comments on drafts of this essay.

${ }^{2}$ Sen (1992), Nussbaum (1995) and March and Olsen (1995, 91-139) argue that developing capabilities is a central and distinctive role of the state. While I agree, I am happy to conceive this as a particularly strategic kind of provision, as by developing capabilities through state provision of education, training, science funding and opportunities for political deliberation, among other public goods.

${ }^{3}$ There is merit in Julia Black's (2002) view that for some analytic purposes narrower conceptualizations of regulation as steering through state rules or law can have more use, while for others broader conceptualizations that do not require the purposiveness of steering, that allow in Foucauldian governmentalities for example, can have more analytic use.
} 
regulation part of governance and less with providing4. Yet non-state regulation has grown even more rapidly, so it is not best to conceive of the era in which we live as one of the Regulatory State, but of Regulatory Capitalism (Levi-Faur 2005).

The first section of the essay argues that Regulatory Capitalism is not about neoliberalism, indeed that those who think we are in an era of neoliberalism are mistaken. The historical forces that have produced Regulatory Capitalism are then sketched as a Police Economy that evolved from various Feudal economies, the supplanting of police with an Unregulable 19th Century Liberal Economy, then the State Provider Economy (rather than the "welfare state") that gives way to Regulatory Capitalism. In the era of Regulatory Capitalism, more of the governance that shapes the daily lives of most citizens is corporate governance than state governance. The corporatisation of the world is both a product of regulation and the key driver of regulatory growth, indeed of state growth more generally. The big conclusion of the essay is that the reciprocal relationship between corporatisation and regulation creates a world in which there is more governance of all kinds. 1984 did arrive. The interesting normative question then becomes whether this growth in hybrid governance contracts freedom, or expands positive liberty through an architecture of separated powers that check and balance state and corporate dominations. While the essay sets up this quandary of our time, it does not answer it.

\section{The Neoliberal Fairytale}

A widely believed chronology, on the left and the right, is that from the end of the 1970s neoliberalism conquered the world (Chomsky 1999). "What is neoliberalism? A programme for destroying collective structures which may impede the pure market logic" (Bourdieu 1998, 2). In the Foucauldian

\footnotetext{
${ }^{4}$ They may have become less preoccupied with distributing as well, but here there is not so clear a body of empirical evidence on trends, so this is not an issue addressed in this essay.
} 
tradation, the methodological prescription is to study neoliberalism as a program rather than as a reality. Of course it is possible, indeed likely, that neoliberalism as a program has all sorts of real, unintended effects on the world without actually creating a neoliberal world. My interest in this section, however, is limited to whether neoliberalism has become an institutional reality. Institutionally, neoliberalism means privatisation, deregulation, including a deregulated international trade regime, and a diminished public sphere. During the 1970s, according to one conventional chronology, the Keynesian welfare state that we had known since the New Deal died. Hayek, a scorned intellectual for most of his life, replaced Keynes as the ascendant inspiration of political economy (Peters 1999). Not only had Keynes been sidelined, the dominant intellectual alternative to him in the academy - Marx was also about to wither away. The fairytale continues that decisive political moments for this tumultuous change in the world of ideas were the election of Margaret Thatcher in the UK in 1979 and Ronald Reagan in the US in 1980. The Hayekian prescriptions of these leaders were for small government, privatisation and deregulation. The revolution quickly seemed complete when Labor governments in Australia and New Zealand in the early 1980s bought in to policies of privatisation and deregulation. Indeed New Zealand took these to greater heights than seen in Thatcher's Britain, just as Ireland later took her low corporate tax policies to deeper lows. The lessons of Labor in the Antipodes were not lost at the Metropoles. It was necessary for Blair and Clinton to be New Labour, New Democrats, not "tax and spend" social democrats. The leadership was English speaking; it was not until the late 1990s that the German social democrats seized power after they learnt to be "New".

The "Chicago boys" 5 were sending missionaries to places like Latin America as well. The leadership of the likes of Carlos Menem in Argentina was lionized by

\footnotetext{
${ }^{5}$ Hayek moved to the University of Chicago in 1950, where he joined his influential disciple, Milton Friedman.
} 
the IMF as demonstrating the neoliberal path out of underdevelopment. Shortlived improvements in the performance of countries such as Argentina and New Zealand, which had been the developed economies that had performed worst during the Provider State era, were not interpreted by neoliberal missionaries as regression to the mean, but as fundamentally effective transformations. When they started performing worse than more regulated economies, the IMF, oblivious, continued to tout their virtues. Some thought this showed that Keynes was right after all - that there was nothing so influential as the ideas of a dead economy. ${ }^{6}$

Ignoring the fact that the Soviet economy had outperformed the US and UK for most of the industrial capitalist era from World War I to 1970 (Castells 2000, 1019), Reagan and Thatcher believed that their military and economic strength so persuaded Gorbachev that socialist economies could never work that, well, he just gave up and ultimately handed over the keys to the Soviet economy to the Margaret Thatcher Foundation and other Anglo-Saxon neoliberal missionaries. ${ }^{7}$ This was the "End of History" (Fukuyama 1989). Neoliberalism was now the "Washington Consensus". Once the entire Second World had signed up to the Washington Consensus, one by one Third World nations fell into line, pushed by the IMF to hire consultants from New Zealand to explain how they had seen the light.

China was a minor exception. But Tiananmen Square in 1989 showed that it was only a matter of time before China realised that neoliberalism would fix its economic malaise, just as it was fixing Russia. Die-hard Keynesians pointed

\footnotetext{
${ }^{6}$ And indeed the New Zealand economy has been performing outstandingly under the more Keynesian policies of the current Prime Minister, Helen Clark.

${ }^{7}$ Of course Gorbachev really did believe in Glasnost and Perestroika, really did believe that a continuing arms race with the US was not in the economic interests of his people or the security interests of the world, and did have the vision to see that Soviet economic planning that had worked quite productively during the heyday of Fordist industrialism, would never flourish under the post-Fordist production imperatives of the information age (see Castells 2000, 2-67).
} 
feebly to other Dragon economies in Asia as achieving sustained economic growth at a level that was consistently outpacing all the neoliberal economies. The Washington Consensus explained it was a myth that these were strong states with dirigiste industrial policies and comparatively egalitarian distributions of wealth. Actually they were just complicated examples of neoliberalism working in more mysteriously oriental ways. When the Tigers hit the Asian Financial Crisis of 1997, there was a sigh of relief as this interpretation shifted. These were not neoliberal economies after all. The IMF needed to go in and demand that they learn all the lessons of the Washington Consensus, not just pick and choose from its reform menu.

The twisting and turning in Asia was the end of the fairytale, the last gasp of neoliberalism as a coherent ideology that pretended to rule the world. Not only did Asia recover quickly to higher growth than the First and Second Worlds, Joseph Stiglitz (2002) convinced growing numbers of economists that the economies that recovered quickest were those, like Malaysia and South Korea, that most aggressively rejected the advice of the IMF. The Washington Consensus finally collapsed under the brute fact that Asia was, after all, not a minor exception, but half the world, and the half that was performing best economically. If there is a widely shared economic orthodoxy in the current decade, in Asia it is becoming more a "Beijing Consensus" (Ramo 2004) than a Washington one. Keynes was alive and well in the hands of regulatory economists like Nobel laureate Joseph Stiglitz - who shaped Washington thinking during the 1990s as Chair of the Clinton Council of Economic Advisors and as Wolfensohn's Chief Economist at the World Bank. Stiglitz is to Regulatory Capitalism as Milton Freidman and the Chicago School were to neoliberalism.

Just as a New Zealand Labour government in the 1980s could be more neoliberal than Reaganites and Thatcherites, so in the current decade the Bush 
administration has turned out to be more Keynesian than the New Democrats it supplanted. Gone is the fiscal rectitude of the Clinton years. The Bush Administration managed the 2001-2 recession with an expansionary Keynesian fix. John Howard's conservative Australian government likewise outKeynesed the new social democrats it supplanted, though not by racking up the huge deficits of the Bush administration. It did so with an unparalleled tax and spend binge, funded by a decade of corporate tax collection growth to 2005 at three times the rate of GDP growth (Braithwaite 2005: Chapter 2). This was accomplished through improved regulatory technologies while reducing the corporate tax rate, so Howard looked like Thatcher while acting like Keynes. A government that collects more tax through reducing profit shifting by multinationals and reducing the movement of the cash of wealthy individuals into tax havens, as the Howard government has done, can boost domestic demand without racking up a deficit. Howard's big government Regulatory Capitalism delivered very strong growth compared to other Western economies and to Australia's own past performance.

The Asian Financial Crisis aftermath was but a last gasp of neoliberalism. It had already been dealt a fatal blow by its triumph in the Second World. The privatisation that the IMF and the likes of the Margaret Thatcher Foundation insisted upon in Russia was a disaster. By the rouble crisis of 1998, Russian GDP had fallen to almost half what it had been at the end of Communism (Stiglitz 2003). It has been growing vigorously since, on the back of surging prices for its oil exports, but will take quite a few more years to return to the comparative prosperity it enjoyed under communism. Some former Soviet states fared even worse. The Washington Consensus adapted to the "Washington Consensus Plus". The "plus" was "good governance" and the "rule of law". In fact the ideology of the Washington Consensus Plus was getting close to what Levi-Faur (2005) describes as Regulatory Capitalism. For neoliberals, regulation remained a dirty word. "Good governance" and "rule of 
law" was a way for them "not to talk about the war" they had lost for the hearts and minds of the world's policymakers.

This is not to deny that the Chicago assault had a permanent impact insinuating market values into what had been the public sphere. Yet Jody Freeman (2003) points out that in addition to the privatisation of the public, we have seen considerable publicisation of the private - progressively more potent infiltration of public law values like transparency into what is expected of public companies. There is no point speculating whether it is the privatisation of the public or the publicisation of the private which is the more important development, as they are incommensurable. Both have been important. There are few people at the top of large American corporations today persuaded by Milton Friedman's prescription that it is wrong to use shareholders' funds for any purpose other than maximizing profits. Commitment in corporate America to having a sound triple bottom line - financial, environmental, social - is now widespread. Green and public values have permeated what Grabosky (1994) calls "Green Markets", wherein market imperatives to be green are more potent than state regulatory imperatives. Green markets are mediated by the interventions of private/NGO regulators such as Forest Stewardship Council certifications of the sustainability of the practices that deliver furniture to the stores of European retailers. Eco- and social-labelling are about harnessing the market choices of consumers to regulatory projects of green, labour and human rights social movements. Part of what Regulatory Capitalism means is using markets as regulatory mechanisms, as opposed to the neoliberal schema of markets as the antithesis of regulation. The state increasingly experiments in creating markets for tradable pollution permits with the objective of creating more cost-effective pollution control, carbon taxes to internalise externalities of markets, and more. The neoliberal program Bourdieu $(1998,2)$ characterised as "destroying collective structures which may impede the pure market logic" 
has retreated in the face of a Regulatory Capitalist reality of hybridity between the privatisation of the public and publicisation of the private.

\section{The Myth of Deregulation}

It had been the case from the early 1980s that there had been, except perhaps in New Zealand, a wide gulf between what the Anglo-Saxon neoliberals said and what they did. The Washington Consensus, Stiglitz $(2004,23)$ alleges, was never what its executors believed was good for Washington; it was never what Washington did; it was what Washington believed was good for other countries to do because it would benefit American business operating in those other countries. Washington econocrats knew a collapse of business regulation was bad for America, but it was mostly good for American multinationals when

other countries eschewed regulatory burdens upon American investments/exports. "The medicine we dispensed abroad was, in important respects, not really the same stuff we drank at home." (Stiglitz 2004, 23)

Actually, this is not quite right. In the first two Reagan years there was genuine deregulatory zealotry. But by the end of the first Reagan term, business regulatory agencies had resumed the long-run growth in the size of their budgets, the numbers of their staff, the toughness of their enforcement and the numbers of pages of regulatory laws foisted upon business (Ayres and Braithwaite 1992, 7-12). Overall, real business regulatory spending increased 10 per cent during the Reagan years (Tramontozzi and Chilton 1988). Environmental deregulation proved so unpopular as to drive from office by early 1983 a deregulatory zealot like Anne Gorsuch, to whom Reagan had handed stewardship of the Environmental Protection Agency. Later in the Reagan administration financial deregulation came unstuck with a Savings and Loans debacle that cost American taxpayers over \$200 billion (Rosoff et al 2002, 255). In this domain, the Reagan and Thatcher governments actually reversed direction globally as well as nationally. The Federal Reserve (US) and Bank of 
England led the world down to financial deregulation in the early 1980s, then led global prudential standards back up through the G-10 after the banking crises of the mid-80s for fear of the knock-on effects foreign bank collapses could have on American business (Braithwaite \& Drahos, 2000,4). By the end of the Reagan administration, the enfeeblement of the regulation of Wall Street in the early 1980s was being ridiculed even in Hollywood by Michael Douglas's portrayal of the insider trader who believed that "greed is good". By then New York Republican prosecutor, Rudolf Giuliani, was building a big political reputation by slapping handcuffs on Wall Street icons like Michael Milkin, inventor of the junk bond. The current Republican administration has presided over a $42 \%$ increase in regulatory staffing levels since 2001 to 242,473 full-time equivalents by 2005. Admittedly 56,000 of the increase were airport screening agents in the Transportation Security Agency (Dudley \& Warrren 2005, 1).

In Britain, privatisation proliferated in a way that created a need for new regulatory agencies. When British telecommunications was deregulated in 1984, Oftel was created to regulate it; Ofgas with the regulation of a privatised gas industry in 1986, OFFER with electricity in 1989, OfWat with water in 1990, and the Office of the Rail Regulator (mercifully not Ofrails!) in 1993 (Baldwin, Scott \& Hood 1998, 14-21). When the Thatcher government radically shifted the provision of nursing home beds from the public to the private sector (Day and Klein, 1987), 200 little nursing home inspectorates were set up in district health authorities to upgrade the previously cursory regulatory oversight of the industry, later consolidated by the Blair government into a Social Care Inspectorate of 2600 inspectors. This led Patricia Day and Rudolf Klein as early as the mid-80s to be speaking of the rise of a new regulatory state in the health and welfare sector. Privatisation combined with new regulatory institutions is the classic instantiation of Osborne and Gaebler's (1992) prescription for reinventing government to steer rather than row. Jordana and Levi-Faur (2003, 2004) show that the tendency for state regulation to grow with privatisation is a 
global one. As privatisation spreads, they find new regulatory agencies spread even faster, and they show how the diffusion of regulatory agencies moved from the West to take off in Latin America in the 1990s.

Francis Fukuyama (2004), the same who told us that the "End of History" had arrived with a Washington Consensus that was the "end point of mankind's ideological evolution" and the "final form of human government" (Fukuyama 1989), now agrees that Russian privatisation was a disaster because "privatisation inevitably creates huge information asymmetries, and it is the job of governments to correct them" (Fukuyama, 2004, 18). Moreover, he reports Milton Friedman saying that in the early 90s he had three words for countries making the transition from socialism: "privatise, privatise, privatise". "But I was wrong," Friedman continues. "it turns out that the rule of law is probably more basic than privatisation." (Fukuyama 2004, 19). Fukuyama $(2004,18)$ also attributes the financial crises experienced by Thailand and South Korea to "premature capital account liberalization in the absence of adequate regulatory institutions". Finally he interprets the strong correlation between per capita GDP and the percentage of GDP extracted by governments as evidence that a strong state is vital for long-term economic growth.

In summary, while the neoliberal policy package of smaller government, privatisation and deregulation was never an accurate way of describing what was happening in the US or UK, it at least was a description of what the "Chicago boys" and the IMF thought should be happening. And it was something global corporations saw themselves as having an interest in promoting in the Second and Third Worlds, even if the business agents of the ideology did not really see it as sound economics. Today there is scant sign of ideological consensus on anything like this neoliberal package. Yet big policy changes in many countries were justified by the rhetoric of neoliberalism. 
At a certain level there is more consensus than during the Cold War. Neither Marx nor Milton Friedman are the ideological forces they once were. The consensus is not liberal. Guantanamo Bay, the profiling and detention of citizens generally, the burgeoning punitive-police apparatus of the crime control, has revealed the Bush Administration and the American judicial branch to be anything but liberal in its limitation of state power over individuals. Neoconservative perhaps, neoliberal hardly. The consensus shared by the policy communities around both Bush and Clinton is quite a confined one in favour of strong markets and a strong state. But there is dissensus on how those strong markets should be regulated, how its fruits should be distributed and to what ends the regulatory power of the state should be directed.

If neoliberalism is neither the end of history nor even a useful way of describing what was happening during a passing moment, what is an analytically insightful way of describing recent institutional history? I used to describe the key transition as one from the liberal nightwatchman state, to the Keynesian welfare state, to the new regulatory state (after 1980) and a regulatory society (see also Majone, 1994; Loughlin and Scott, 1997; Parker, 1999; Jayasuriya, 2001; Midwinter \& McGarvey, 2001; Marcus, 2002; Moran, 2003). The nub of the regulatory state idea is power is deployed "through a regulatory framework, rather than through the monopolization of violence or the provision of welfare" (Walby, 1999, 123). Now I prefer Levi-Faur's (2005) adaptation of the regulatory state idea into Regulatory Capitalism. According to Levi-Faur, we have seen since 1980 not only what Vogel (1996) found empirically to be Freer Markets, More Rules, but also "more capitalism, more regulation". Privatisation is part of Levi-Faur's characterisation of Regulatory Capitalism. But it sits alongside proliferation of new technologies of regulation and meta regulation (Parker 2002), or control of control (Power 1996), increased delegation to business and professional self-regulation and to civil society, to intra- and international networks of regulatory experts, and increased regulation of the 
state by the state, much of it regulation through and for competition. ${ }^{8}$ The Regulatory Capitalism framework theorises the New Public Management post1980 as a conscious separation of provider and regulator functions within the state, where sometimes the provider functions were privatised and regulated, and sometimes they were not privatised but nevertheless subjugated to the "audit society" and government by (audited) contract (Power 1996).

The Keynesian welfare state now seems a poor description of the institutional package that dominated until 1980. One reason is that Keynes is alive and well not only in the political economy of new social democrats like Tony Blair, but in neoconservatives like George W. Bush and John Howard. Second, it is not true that the state has hollowed out - Bush and Howard are by far the most profligate spenders their nations have seen. Nor has the welfare state atrophied. Welfare state spending by rich nations has not declined (Castles 2004). Finally, the State Provider Economy was not just about providing welfare; it was about states providing transport, industrial infrastructure, utilities and much more beyond welfare, a deal of which was privatised in the transition to Regulatory Capitalism.

Even the idea of the nightwatchman state of the 19th century needs qualification. The prehistory of the institutional change summarized in this paper could be described as a transition from various feudalisms to a Police Economy. The sequence I will describe is a transition then from that Police Economy to the Unregulable Economy tending to laissez faire after the collapse of police, to the "State Provider Economy" (rather than the "welfare state") to "Regulatory Capitalism" (rather than the "regulatory state").

\footnotetext{
${ }^{8}$ Hood et al (1999) count 135 separate regulators of British government within British government, employing 14,000 staff.
} 


\section{The Police Economy}

What does Tomlins $(1993,37-8)$ mean when he says that writing a history of the American state without a reference to the genealogy of "police" is "akin to writing a history of the American economy without discussing capitalism?" In the white settler societies it is easier to see with clarity the Police Economy because it did not have to struggle to supplant the old economy of monopolies granted by the king to guilds, market towns and trading companies like the Hudson Bay Company (even as the New World was partly constituted by the latter). That economy of monopoly domination granted by the king was not only an earlier development in the transition from feudalism to capitalism that was subsequently (de)regulated by police, it was also a development largely restricted to cities which were significant nodes of manufactures and longdistance trade. ${ }^{9}$ Tiny agricultural communities that did not have a guild or a chartered corporation had a constable. The early modern idea of police differs from the contemporary notion of an organization devoted to fighting crime (Garland, 2001). Police from the $16^{\text {th }}$ to the $19^{\text {th }}$ century in Continental Europe meant institutions for the creation of an orderly environment, especially for trade and commerce. The historical origins of the term through German back to French is derived from the Greek notion of "policy" or "politics" in Aristotle (Adam Smith 1978, 486; Neocleous 1998). It referred to all the institutions and processes of ordering that gave rise to prosperity, progress and happiness, most notably the constitution of markets. Actually it referred to that subset of governance herein conceived as regulation.

Police certainly included the regulation of theft and violence, preventive security, regulation of labour, vagrancy and the poor, but also of weights and measures and other forms of consumer protection, liquor licencing, health and safety, building, fire safety, road and traffic regulation and early forms of

\footnotetext{
${ }^{9}$ France was an exception that made guilds state organs and spread their regulatory authority out from towns across the entire countryside (Polanyi, 1957, 66).
} 
environmental regulation. The institution was rather privatised, subject to considerable local control, relying mostly on volunteer constables and watches for implementation, heavily oriented to self-regulation and infrequent (even if sometimes draconian) in its recourse to punishment. The lieutenant de police (a post established in Paris in 1667) came to have jurisdiction over the stock exchange, food supplies and standards, the regulation of prostitutes and other markets in vice and virtue. Police and the "science of police" that in $18^{\text {th }}$ century German universities prefigured contemporary regulatory studies ${ }^{10}$ sought to establish a new source of order to replace the foundation laid by the estates in the feudal order that had broken down.

English country parishes and small market towns, as on the Continent, had constables and local watches under a Tudor system that for centuries beyond the Tudors regulated the post-feudal economic and social order. Yet there was an English aversion to conceptualising this as police in the French, German and Russian fashion. The office of the constable had initially been implanted into British common law and institutions by the Norman invasion of 1066 . The office was in turn transplanted by the British to New England, with some New England communities then even requiring Native American villages to appoint constables. Eighteenth century English, but not American, ${ }^{11}$ political instincts were to view Continental political theory of police as a threat to liberty and to

\footnotetext{
${ }^{10}$ Pasquino $(1991,112)$ reports a 1937 bibliography for German-Speaking areas that lists 3,215 publications from 1600 to 1800 under the listing, "science of police in the strict sense".

${ }^{11}$ The emerging American republics gave a republican interpretation to police, as did many European intellectuals of the science of administration and police. Police was partly about restraining the power of the king. It denoted both the condition of a just and free social order and the means for securing that order - local governance that steers a polity toward republican freedom (Tomlins 1993, 35-59). The Delaware Declaration of Rights of 1776 stated "that the people of this State have the sole exclusive and inherent Right of governing and regulating the internal Police of the same.” Pennsylvania, Maryland, North Carolina and Georgia adopted the same formulation, or a similar one, over the next year (Tomlins 1993, 57). Many a history book says that when Jefferson was elected to the Board of Visitors of the College of William and Mary in 1779, his advocacy pioneered the first chair of Law in North America at a time when the only other in the world was the Vinerian Chair at Oxford. Of course there were a number of chairs of the science of police on the Continent at this time. And actually the title Jefferson chose for the William and Mary Chair was "Law and Police." Jefferson believed in the guidance of the economy not
} 
seek a more confined role for the constable. Admittedly, Blackstone in his fourth volume of Commentaries on the Laws of England (1769) adopts the Continental conception of police, and Adam Smith applauds it in his Lectures on Jurisprudence (1762-4). But Neocleous (1998) detects a shift from the Smith of the Lectures to the Wealth of Nations, both of which discuss police and the pin factory. The shift is from seeing:

police power contributing to the wealth-producing capacities of a politically constituted social order to being a site of autonomous social relations - the independent factory employing independent wagelabourers within a laissez faire economy...

Polanyi $(1957,66)$ quotes Montesquieu as sharing the early Smithian view of English police as constitutive of capitalism, when he says in the Spirit of Laws that "The English constrain the merchant, but it is in favor of commerce." Even as institutions of $18^{\text {th }}$ century police are to a considerable degree in place in the nations that become the cutting edge of capitalism (this is also true of the extremely effective policing of the Dutch Republic (Israel 1995, 677-84)), the leading interpreters of capitalism's success move from an interpretation of markets constituted by police to laissez faire markets.

Peel's creation of the Metropolitan Police in London in 1829 and the subsequent creation of an even more internationally influential colonial model in Dublin were watersheds. Uniformed paramilitary police, preoccupied with the punitive regulation of the poor to the almost total exclusion of any interest in the constitution of markets and the just regulation of commerce, became one of the most universal of globalised regulatory models. So what happened to the business regulation? From the mid-19th century, factories inspectorates, mines inspectorates, liquor licensing boards, weights and measures inspectorates, health and sanitation, food inspectorates and countless others were created to

only by a rule of national law, but much more fundamentally by a governance of local, participatory police. 
begin to fill the vacuum left by constables now concentrating only on crime. Business regulation became variegated into many different specialist regulatory branches. The 19th century regulatory growth is more in the number of branches than in their size and power. Laissez faire ideology underpinned this regulatory weakness. The regulators' feeble resourcing compared to the paramilitary police, and the comparative wealth of those they were regulating, made the early business regulators even more vulnerable to capture and corruption than the police, as we see with poorly resourced business regulators in developing economies today.

\section{The Unregulable Liberal Economy}

Where problems were concentrated in space, 19th century regulation secured some major successes. Coal mines became much safer workplaces from the latter years of the 19th century, as did large factories in cities (Braithwaite 1985), regulatory transitions that are yet to occur in China that today accounts for $80 \%$ of the world's coal mine fatalities. Rail travel was causing thousands of deaths annually in the US late in the nineteenth century (McCraw1984, 26); by the twentieth century it had become a very safe way to travel (Bradbury 2002). Regulation rendered ships safer and more humane transporters of exploited labour (slaves, convicts, indentured labour, refugees from the Irish famine) to corners of empire suffering labour shortages (Macdonagh 1961). The paramilitary police were also successful in assisting cities like London, Stockholm and Sydney to become much safer from crimes against persons and property for a century and a half from 1820 (Gurr et al, 1977). But it was only problems like these that were spatially concentrated where 19th century regulation worked. In most domains it worked rather less effectively than 18th century police. This was acceptable to political elites, who were mainly concerned to 
make protective regulation work where the dangerous classes might congregate to threaten the social order - in cities, convict ships, factories. ${ }^{12}$

In addition to the general underresourcing of $19^{\text {th }}$ century regulatory inspectorates, the failure to reach beyond large cities, ${ }^{13}$ the capture and corruption, there was the fact that the inspectorates were only beginning to invent their regulatory technologies for the first time. They were still learning. The final and largest limitation that made their challenge impossible was that in the 19th century almost all commerce was small business. It is harder for an inspector to check 10 workplaces employing 6 people than one with 60 workers. This remains true today. We will see that the regulatory reach of contemporary capitalism would be impossible without the lumpiness of a commerce populated by big businesses that can be enrolled to regulate smaller businesses. Prior to the 19th century, it was possible to lever the self-regulatory capabilities of guilds in ways not dissimilar to $20^{\text {th }}$ century capabilitities to enrol industry associations and big business to regulate small business. But the well-ordered

\footnotetext{
${ }^{12}$ In the village or the rural sweatshop the centralized regulatory agencies offered little protection. To a considerable extent that is still true today. If you live in an Australian outback town, you put up with a lot of crime and there is not much you can do if the butcher sells you underweight meat or if the two petrol stations in town collude to charge an outrageous price. In the city you could complain to a consumer protection regulator who would check out the complaint. Out back the metropolitan offices of the regulator are too far away for that to be feasible. A radical solution would be to deputise and train police in the bush as delegates of consumer protection, fire safety, nursing home, food safety and other regulators. The only way for rural communities to get their fair share of the regulatory state may be to go back to the 18th century constable. Clifford Shearing has been an advocate of giving remote and marginal people a claim to their share of a policing budget (as opposed to a police force budget) to reinstate a form of Jeffersonian police for an era of Regulatory Capitalism (Shearing \& Wood 2003). The bush also lost out to the city with the move away from the Provider State after 1980. When the PostMaster General provided the phone service, country folk could at least get their local member to do something about poor service. Police and weights and measures inspectorates worked up to a point in the $19^{\text {th }}$ century city. But they left the hinterland unregulable, plundered by highwaymen and commercial crooks. The far West of Australia's Eastern states remain wild in a way akin to the wild West that President Jefferson opened up to a liberal $19^{\text {th }}$ century economy he would have been disappointed to see. Contemporary Australian outback towns today are likewise afflicted with high levels of violence, buildings that are firetraps, occupational health and safety practices that are scandalous. Such places have lost many of the virtues of agrarian republicanism without gaining many of the civilising influences the Provider State and the Regulatory State supplied to cities.

${ }^{13}$ For example see Clarke's (1986) characterisation of British club governance as Regulating the City. And see Moran (2003) for the most influential discussion of British club governance. The para-military crime police, as we have already implied, also succeeded only in regulating large cities in the nineteenth century.
} 
world of guilds had been one of the very things destroyed by the chaotic emergence of laissez faire capitalism outside the control of such pre-modern institutions. Where guilds did retain control, capitalism did not flourish, because the guilds restricted competition.

While the 19th century state was therefore mostly a laissez faire state with very limited reach of its capacity to regulate, it was a state learning to regulate. While the early $19^{\text {th }}$ century tension was Smith's between the decentralised police economy and laissez faire liberalism, the late century tension was between laissez faire and the growth of an administrative state of office blocks in large cities. The late $19^{\text {th }}$ century was both more disciplined by the market and more disciplined by growing state capacity to govern.

\section{The Unregulable Liberal Economy Creates the Provider State}

A simple solution to the problem of private rail companies charging monopoly prices, by-passing poorer towns, failing to serve strategic national development objectives and flouting safety standards was to nationalise them. A remedy to unsanitary private hospitals was a public hospital system that would make it unnecessary for patients to resort to unsafe private providers. The challenge of coordinating national regulation of mail services with international regulation through the Universal Postal Union (established 1863) rendered a state postal monopoly the simplest solution to coordination otherwise beyond the unregulable 19th century liberal economy. The spread of socialist ideas during the 19th century gave an ideological impetus to the Provider State solution. Progressively until the beginning of the second half of the 20th century, the provider state model proliferated, especially in Europe, with airlines, steel, coal, nuclear power, urban public transport, electricity, water, gas, health insurance, retirement insurance, maternal and child welfare, fire fighting, sewerage and countless other things being provided by state monopolies. 
Bismarck consciously pursued welfare state provision as a strategy for thwarting the growing popularity of the idea of a socialist revolution to replace capitalism entirely with a state that provided everything. Lloyd-George was impressed by Bismarck's diagnosis and the British Liberal Party also embraced the development of the welfare state, only to be supplanted by a Labour Party that outbid the Liberals with the state provision it was willing to provide workers who now had votes and political organization.

While many of these state takeovers also occurred in the United States during the century and a half that preceded Levi-Faur's arrival of Regulatory Capitalism, the scope of what was nationalized was much narrower there. One reason was that trade unions and the parties and socialist ideologies they spawned were much weaker in the US during the 20th century. There were periods up to the first decade of the $20^{\text {th }}$ century when trade unions in the United States were actually numerically and politically stronger than in Europe. The big businesses that grew earlier in the United States used their legal and political capabilities to crush American unionism in the late 19th and early 20th century, frequently through murder of union officials and threats of violence (Braithwaite \& Drahos 2000, 229). American big business could simply organize more effectively against the growth of trade unions and the provider state ideologies they sponsored than the smaller family firms that predominated in Europe.

A paradox of the fact that American business culture moderated the growth of the provider state was that the regulatory state grew more vigorously in the US, especially during the progressive era (1890-1913) (which saw the creation of the Federal Trade Commission, Food and Drug Administration, and Interstate Commerce Commission, among other agencies) and the New Deal (1930s) (which saw the creation of the Securities and Exchange Commission, the National Recovery Administration, the Federal Communications Commission, 
the Civil Aeronautics Board, among others) (McCraw 1984). Building paradox upon paradox, the growth in the sophistication of regulatory technologies in the US showed that there were credible alternatives to the problems the Provider State set out to solve. The New Deal also supplied an economic management rationale to an expansive state. Keynes general theory was partly about increasing public spending to stimulate an economy when it was in recession, as it was at the time of the New Deal.

\section{Regulation Creates Big Business}

Braithwaite and Drahos (2000) have described the corporatisation and securitisation of the world as among its most fundamental transformation of the last three centuries. ${ }^{14} \mathrm{I}$ will summarize here how this was enabled by regulation, but then how corporatisation in turn enabled Regulatory Capitalism to replace the Provider State Economy. Corporations existed for more than a millennium before securities. For our purposes, a security is a transferable instrument evidencing ownership or creditorship, as a stock or bond. The legal invention of the security in the 17th century was the most transformative moment in the history of corporations. It enabled the replacement of family firms with very large corporations based on pooled contributions of capital from thousands of shareholders and bondholders. These in turn enabled the great technological projects of 18 th and 19th century capitalism - the railroads, the canals, the mines.

When it was first invented, however, the historical importance of the security had nothing to do with the corporatisation of the world. Rather, it transformed state finances through bonds that created long-term national debts. ${ }^{15}$ While the

\footnotetext{
${ }^{14}$ Corporatisation and securitisation are themselves part of a deeper historical process of propertisation in which assets both tangible and intangible become subject to regulation by formal property rights that enable these assets to be traded (Drahos 2002).

15 Today as well, some of the most important securitisation involves a transformation of banking and finance that does not involve the creation of new corporations. An example is mortgage-backed
} 
idea of dividing the national debt into bonds was invented in Naples in the 17th century, it was England that managed by the 18th century to use the idea in a financial revolution that helped it gain an upper hand over its principal rival, France (Dickson 1993). England became an early provider state in a particularly strategic way by seizing full national control of public finance: formerly private tax and customs collecting were nationalised in the 17th century, a Treasury Board was established in the 18th, and finally the Bank of England was given national regulatory functions. The Treasury Board realised that the national debt could be made in effect self-liquidating and long term, protecting the realm from extortionate interest rates at times of war and the kind of vulnerability that had brought the Spanish empire down when short-term loans had to be fully repaid after protracted war. Instead of making England hostage to Continental bankers, the national debt was divided into thousands of bonds, with new bond issues placed on the market to pay for old bonds that were due to be paid.

Securitisation paid for the warships that allowed Britannia to rule the waves, to trade and colonise - to be a state provider of imperial administration and national as opposed to feudal security on a scale not imagined before. Today of course national debts no longer can be used to rule the world because they are regulated by other states through the Paris Club and the IMF. The key thing here is that the early providers of state control of public finance in the process also induced a private bond market. This created the profession of stockbroking and the institution of the stock exchange. For most of the periods when Amsterdam and London were the leading stock exchanges in the world, they were predominantly trading securities in the debts of nations. Gradually this created a market in private stocks and bonds. These enabled the English to create the Massachusetts Bay Company, the Hudson Bay Company, the British

securities - securities backed by bundles of loans on real estate, automobiles or credit cards issued by banks. 
South Africa Company, the East India Company and others that conquered the world and the Dutch to create an even more powerful East India Company and the United New Netherland Company that built a New Amsterdam which was to succeed London as the next capital of the world.

State creation of a London market in the broking of securities fomented other kinds of securities exchanges as well, the most important of which was Lloyd's of London. Britannia's merchant fleet ruled the waves once an efficient market in spreading the lumpy risk of ships sinking with valuable cargos was created from a base in Lloyd's Coffee Shop. Lloyd's in turn became an important inventor of regulatory technologies that made regulatory capitalism possible in advance of the supplanting of the Provider State with Regulatory Capitalism. For example, in building a global reinsurance market it invented the Plimsoll line that allowed insurers to check by simple observation at ports whether ships arrived overloaded.

But by far the most important impact of securitisation was that it began a process that only took off quite late in the 19th century of replacing a capitalism of family firms with one of professional managers of securities put in their trust by thousands of shareholders. Even in New York, where the corporatisation of the world was most advanced, it was not until the third decade of the 20th century that the majority of litigants in appellate courts were corporations rather than individual persons and the majority of actors described on the front page of the New York Times were corporate rather than individual actors (Coleman, 1982: 11).

\section{Antitrust Globalizes American Mega-Corporate Capitalism}

In the 1880s, predominantly agrarian America became deeply troubled by the new threat to what they saw as their Jeffersonian agrarian republic from concentrations of corporate power that they called trusts. Farmers were 
especially concerned about the "robber barons" of railroads that transported their produce across the continent. But oil, steel and other corporate concentrations of power in the North-East were also of concern. Because Jeffersonian republicanism also feared concentrations of state power in the North-East, the American solution was not to nationalise rail, oil and steel. It was to break up the trusts. By 1890 at least ten US states had passed antitrust laws, at which point the Sherman Act was passed by a virtually unanimous vote of the US Congress.

The effect of enforcement of the Sherman Act by American courts was not exactly as intended by the progressive era social movement against the railroad, oil, steel and tobacco trusts. Alfred Chandler, Jr., noted that "after 1899 lawyers were advising their corporate clients to abandon all agreements or alliances carried out through cartels or trade associations and to consolidate into single, legally defined enterprises" (Chandler 1977, 333-4). US antitrust laws thus actually encouraged mergers instead of inhibiting them because they "tolerated that path to monopoly power while they more effectively outlawed the alternative pathway via cartels and restrictive practices" (Hannah 1991, 8). The Americans found that there were organizational efficiencies in managerially centralized, big corporations that made what Chandler called a "three-pronged investment": (1) "an investment in production facilities large enough to exploit a technology's potential economies of scale or scope"; (2) "an investment in a national and international marketing and distribution network, so that the volume of sales might keep pace with the new volume of production"; (3) "to benefit fully from these two kinds of investment the entrepreneurs also had to invest in management" (Chandler 1990, 8).

According to Freyer's (1992) study in the Chandler tradition, the turn-ofcentury merger wave fostered by the Sherman Act thrust US long-term organization for economic efficiency ahead of Britain's for the next half century, 
until Britain acquired its Monopolies Act 1948 and Restrictive Trade Practices Act 1956. Until the 1960s the British economy continued to be dominated by family companies that did not mobilize Chandler's three-pronged investment. Non-existent antitrust enforcement in Britain for the first half of the twentieth century also left new small business entrepreneurs more at the mercy of the restrictive business practices of old money than in the US. British commitment to freedom of contract was an inferior industrial policy to both the visible hand of American lawmakers' rule of reason and the administrative guidance of the German Cartel Courts. For the era of managerial capitalism, liberal deregulation of state monopolies formerly granted to Indies Companies and guilds was not enough. Simpleminded Smithean invocation of laissez faire missed the point. A special kind of regulation for deregulation of restrictive business practices was needed which tolerated bigness.

Ultimately, Braithwaite and Drahos (2000) show that this American model of competitive mega-corporate capitalism globalised under four influences: (1) Extension of the model throughout Europe after World War II under the leadership of the German anti-cartel authority, the Bundeskartelamt, a creation of the American occupation; (2) Cycles of Mergers and Acquisition (M\&A) mania in Europe catalysed in part by M\&A missionaries from American law firms; (3) Extension of the model to the dynamic Asian economies in the 1980s and 90s, partly under pressure from bilateral trade negotiations with the US and Europe (who demanded breaking the restrictive practices of Korean chaebol, for example) ; (4) Extension of the model to developing countries with technical assistance from organizations like UNCTAD, prodded by the IMF good governance agenda that succeeded the Washington Consensus. This history of a regulatory capitalism that promotes competition among large corporations from the 1880s (in the US) is very recent in other states. Most of the 
world's competition regulators have been created since 1990. There were barely 20 in the 1980s; today there are about 100.16

\section{Mega-Corporate Capitalism Creates Regulatory Capitalism}

This story is one of reciprocal causation. The regulatory state creates megacorporations, but large corporations also enable regulatory states. We have seen that antitrust regulation is the primary driver of the first side of this reciprocal relationship. But other forms of regulation also prove impossible for small business to satisfy. In many industry sectors, regulation drives small firms that cannot meet regulatory demands into bankruptcy, enabling large corporates to take over their customers (see, for example, Braithwaite's (1994) account of how tougher regulation drove the "mom and pops" out of the US nursing home industry in favor of corporate chains). For this reason, large corporations often use their political clout to lobby for regulations they know they will easily satisfy but that small competitors will not be able to manage. They also lobby for ratcheting up regulation that benefits them directly (eg longer patent monopolies) but that are mainly a cost for small business (Braithwaite \& Drahos 2000, 56-87).

To understand the second side of the reciprocal relationship more clearly mega corporates create Regulatory Capitalism - consider the minor example of the regulation of the prison industry (Harding 1997). It is minor because most countries have not taken the path of privatising prisons, though in the US, where prisons house more than two million inmates and employ about the same number, it is not such a minor business. In the 1990s many private prisons are created in Australia, a number of them owned by the largest American prison corporations. A question that immediately arose was how was the state to ensure that American corporations met Australia's national and

\footnotetext{
${ }^{16}$ I am indebted to Professor Eleanor Fox of New York University in helping me with various sources to reach these figures.
} 
international human rights obligations. When the state was the monopoly provider of prison places, it simply, if ineffectively, told its civil servants that they would lose their jobs if they did not fulfil their duty in respect of such standards. This requirement was put into contracts with the private prisons. But then the state has little choice but to invest in a new regulatory agency to monitor contract compliance.

As soon as it puts this in place, prisoner rights advocates point out that in some respects the old state-run prisons are more abusive than the new private providers, so the prison inspectorate should monitor the public prisons. Moreover, it should make public its reports on the public prisons so that transparency is as real there as with private prisons (Harding 1997). Of course, the private corporations lobby for this as well to create a "level playing field" in their competition with the state. Hence, the corporatisation of the prison industry creates not only a demand for the independent, publicly transparent regulation of the corporates, it also creates a potent political demand for regulation of the state itself. This is central to understanding why the regulatory state is not the correct descriptor of contemporary transformations; Regulatory Capitalism involves heightened regulation of the state as well as growth in regulation by the state (Hood et al 1999). We have seen this in many other domains including the privatisation of British nursing home provision described earlier leading to inspection of public nursing homes.

Security generally has been a major domain of privatisation. Most developed economies today have a ratio of more than three private police to one public police officer (Johnston \& Shearing 2003). Under provider capitalism it was public police officers who would provide security at football stadiums, shopping complexes, universities, airports. But today as we move from airport to shops to leisure activity to work, we move from one bubble of private security to another (Shearing \& Wood, 2003; Johnston \& Shearing 2003). If our 
purse is stolen at the shopping mall, it is a private security officer who will come to our aid, or who will detain us if we are caught shoplifting. The public police mostly cover us only as we move in public space between bubbles of private security. As with prisons, public demand for regulation of the private security industry arises when high profile incidents occur, such as the recent death of one of Australia's most talented cricketers after a bouncer's punch outside a nightclub.

International security has also privatised. Some of those allegedly leading the abuses at Abu-Grahib in Iraq were private security contractors. Many of these contractors carry automatic weapons, dress like soldiers, and are killed as soldiers by insurgents. In developing countries, particularly in Africa, military corporations have been hired to be the strike infantry against adversaries in civil wars. An estimated 70 per cent of the former KGB found employment in this industry (Singer, 2002). This has led the British government to produce a White Paper on the need to regulate private military organizations and to the quip that the regulator be dubbed OfKill!

So the accumulation of political power into the hands of large private corporations creates public demand for regulation. Moreover, we have seen that the largest corporations often demand this themselves. In addition, the regulatory processes and (partly resultant) competitive imperatives that increase the scope and scale of corporations make what was unregulable in the 19th century, regulable in the 20th. The chemicals/pharmaceuticals industry, for example, creates huge public demand for regulation. Incidents like Bhopal with the manufacture of agricultural chemicals and thalidomide with pharmaceuticals, that kill thousands, galvanize mass concern. The 19th century regulatory state could only respond to public outrage by scapegoating someone in the chemical firm and throwing them in prison. It was incapable of putting a regulatory regime in place that might prevent recurrence by addressing the root 
causes of disasters. There were too many little chemical producers for state inspectors to monitor and it was impossible for them to keep up with technological change that constantly created new risks.

After the Bhopal disaster, which ultimately caused the demise of Union Carbide, the remaining large chemical producers put in place a global selfregulatory regime called "Responsible Care", with the objective of averting another such disaster that might cause a multinational to go under leaving a stain on the reputation of the entire industry (Moffet et al 2004). That's all very well, the regulatory cynic notes, but it still remains the case today that most chemical risks are posed by small, local firms with poor self-regulatory standards, not by the multinationals. Yet the fact of mega-corporate capitalism that has evolved over the past century is that almost all small chemical firms are linked upstream or downstream to one multinational or another. They buy or sell chemical ingredients to or from the large corporates. This fact creates a mass tort risk for the multinationals. The multinationals are the ones with the deep pockets, the high public profile and brand reputation; so they are more vulnerable to the irresponsibility of small chemical firms linked to them than are those firms themselves. So Responsible Care requires large firms to sustain a chain of stewardship for their chemicals upsteam and downstream. This has the effect of making large corporations the principal regulators of small chemical firms, not the state. This is especially so in developing countries where the temptations of state laissez faire can make the headquarters risks potentially most catastrophic.

State regulation and private regulation through tort creates larger chemical corporations. We see this especially in pharmaceuticals where the costs of testing new drugs now run to hundreds of millions of dollars. Global scandals that lead to demand for still tougher regulation creates a community of shared fate among large firms in the industry (note Rees's (1994) study of how the 
Three Mile Island disaster created a community of fate in the nuclear industry, a belief that another Three Mile Island could cripple the entire industry). Big business responds to finding itself in a community of fate in a risk society (Beck 1992) by industry-wide risk management. This implies managing upstream and downstream risks. Again we see that Regulatory Capitalism is not only about the regulatory state, though this is a big part of the chemicals, pharmaceuticals and nuclear stories. It is also about regulation by industry associations of their large members and regulation of small producers by large producers who share the same chain of stewardship for a risk. At the end of the day, it is not only states (with technical assistance from international organizations like the World Health Organization and the OECD) doing the regulating, it is global and national industry associations and large multinational firms. Not only does this ease some of the logistical burdens upon the regulatory state in monitoring a galaxy of small firms, it also eases some of the information problems that made chemicals unregulable in the 19th century. As partners in Regulatory Capitalism, state regulators can lean on Responsible Care, the OECD and large multinationals that may know more than them about where new chemical risks are emerging. Of course there is debate about how well these private-public partnerships of Regulatory Capitalism work (Gunningham \& Grabosky 1998).

Braithwaite and Drahos (2000) revealed the importance of yet other actors who are important as non-state regulators. Ratings agencies like Moody's and Standards and Poors, having witnessed the bankrupting of imprudent chemical producers, downgrade the credit rating of firms with a record of sloppy risk management. This makes money more expensive for them to borrow. Reinsurers like Lloyd's also make their risks more expensive to reinsure. The cost and availability of lending and insurance also regulates small firms. Care homes (including nursing homes) frequently go bankrupt in the UK; these bankruptcies are often connected to the delivery of poor quality care. Reports 
of British government Care Home inspections are on the internet. When homes approach banks for loans, it is good banking practice today to do an internet check to see if the home has any looming quality of care problems. If it does, banks sometimes refuse loans until these problems are addressed. Banks have thence become important regulators of little and large British care home firms.

\section{Corporatisation, Tax and the Constitution of Provider and Regulatory}

\section{Capitalism}

One effect of the corporatisation of capitalism in the 20th century was that it made it easier for the state to collect tax. This revenue made it possible to fund both the provider state and the regulatory state. State provision of things like welfare and transport and state regulation are expensive activities. So taxpaying becoming regulable was decisive to the subsequent emergence of the Provider State and Regulatory Capitalism. In most developing societies taxpaying remains unregulable and this has closed the door on credible state provision and state regulation.

Of course it is more cost-effective to collect tax from one large corporation than ten small ones and most corporate tax is collected from the largest $1 \%$ of corporations in wealthy nations. ${ }^{17}$ But this is not the main reason that corporatisation created a wealthy state. More fundamentally, corporatisation assisted the collectability of other taxes (see Braithwaite \& Drahos 2000, Chapter 9). As retailing organizations became larger corporates, as opposed to family-owned corner stores, the collection of indirect tax became more costeffective. When most of the Australian working class was rural, itinerantly shearing sheep for graziers, cutting cane or picking fruit, collecting taxes from

\footnotetext{
${ }^{17}$ In the US in 1997, 9,017 of the 4.71 million corporations had \$250 million or more in assets. This group of less than half a percent of the corporations paid 78\% of the corporate tax collected (Yin 2001, 228). In Australia, the skew is similar but not so extreme: $75 \%$ of company tax collections are from "large" companies with total income over A \$10 million (Wickerson, Reddan \& Khan 2001, 265).
} 
them was difficult and costly. But as the working class became progressively more urban - in the employ of city-based corporations - income tax collections from workers became a goldmine, especially after the innovation of Pay As You Earn (withholding of tax from pay packets by employers, which started in Australia in 1944). The final contribution of mega-corporatisation was financial institutions becoming more concentrated and computerised, making withholding on interest and dividends feasible. So tax on salary income, corporate tax, sales taxes and tax on income from interest and dividends all became more collectable. The result was that, contrary to the fairytale of neoliberalism, the state grew and grew into a regulatory capitalism where the state both retained many of its provider functions and added many new regulatory ones.

Pay as You Earn was an innovative regulatory technology of wider relevance. PAYE taxpayers cannot cheat because it is not them, but their employers, who hand over the money. Theoretically of course the employer can cheat. But they have no incentive to do so, since only their employee benefits from the cheating, and the cheating is visible in the accounts. The regulatory strategy of general import here is to impose regulatory obligations on keepers of a gate that controls the flow of the regulated activity, where the gatekeepers do not benefit personally from opening and closing the gate. This not only separates the power from the incentive to cheat, it also economizes on surveillance. It is not necessary to monitor all the regulated actors at all times. The regulator must only monitor the gatekeeper at those points when gates can be unlocked.

\section{The Regulated State}

For 90 per cent of the world's states there are large numbers of corporations with annual sales that exceed the state's GDP. The CEOs of the largest corporations typically are better networked into other fonts of power than the Presidents of medium-sized states. Consequently large corporations do a lot of 
regulating of states. There are also some smaller global corporations like Moody's and Standards and Poors that have specialised regulatory functions over states - setting their credit ratings. More generally, finance capital holds sway over states. This is exercised through capital movements, but also through lobbying global institutions like the IMF, the Basle Committee, World Trade Organization Panels and the World Bank, who might have more direct control over a specific sphere of state activity. The most formidable regulator of debtor states is the IMF, as a result of its frequently used power to impose regulatory conditions upon debt repayment.

While states have formidable regulatory leverage over airlines, for example, airlines can enrol the International Civil Aviation Organization to regulate landing rights to and from states that fail to meet their obligations to the orderly conduct of international transport. While states regulate telecoms, they must submit to regulation by the International Telecommunication Union if they want interconnectivity with telecoms in other states, and powerful corporations invest heavily in lobbying the ITU and in having their executives chair its technical committees.

Many states simply forfeit domains of regulation to global corporations that have superior technical capability and greater numbers of technically competent people on the ground. For example, in many developing nations the Big Four accounting firms effectively set national accounting standards. States are also regulated by international organizations (and bilaterally) to comply with legal obligations under treaties they have signed. Sanctions range from armed force down to air and sea blockades, suspension of voting rights on international organizations, trade sanctions, and "smart sanctions" such as seizure of foreign assets and denial of visas to members of the regime and their families. Regional organizations such as the European Union and the African Union also of course have a degree of regulatory leverage over member states. 
Leverage tends to be greatest when states are applying for membership of an international club such as the World Trade Organization or EU from which they believe they would benefit.

One of the defining features of Regulatory Capitalism is that parts of states are set up with independent capacities to regulate other parts of the state. We have seen that even Milton Freidman now believes that having an independent judiciary with a real capability to enforce the law against the executive government is a top priority for economic development and a central plank of the World Bank and IMF good governance agenda. But we have also seen since 1980 the globalisation of the Swedish institution of the Ombudsman, a proliferation of audit offices to the point where some describe what Levi-Faur calls Regulatory Capitalism as The Audit Society (Power 1997). Finally, there is the development mentioned earlier of independent inspectors of privatised industries moving their oversight back to public provision.

Of course the idea of a separation of powers where one branch of governance regulates another so that neither executive, judiciary nor legislature can dominate governance is an old one, dating at least from the Spartan constitution and Montesquieu (Braithwaite 1997). But practice has become more variegated, especially in Asian constitutions such as those of Thailand and Taiwan that conceive of themselves as having more than three branches of governance, with branches such as the Election Commission, Ombudsman, Human Rights Commission, Counter Corruption Commission, Audit Offices, Control Yuan and Examination Yuan enjoying Constitutionally separated powers from the legislative, executive and judicial branches. The theory as well as the practice of the doctrine of separation of powers under Regulatory Capitalism has also moved forward on how innovative separations of powers can deter abuse of power (see Braithwaite 1997). To the extent that there are richer, more plural separations within and between private and public powers 
in a polity, there is a prospect of moving toward a polity where no one power can dominate all the others and each power can exercise its regulatory functions semi-autonomously even against the most powerful branch of state or corporate power. As Durkheim began to see, the art of government "consists largely in coordinating the functions of the various self-regulating bodies in different spheres of the economy" (Schepel 2005, Chapter 1; see also Cotterrell, 1999; Durkheim, 1930: 1901 Preface).

Weiss (2005) calls this governed interdependence. What constrains the ability to dominate does not necessarily weaken governance: the state's capacity to govern is actually extended by capabilities to enlist through negotiation the governance capabilities of other actors. As global regulatory regimes expand, state regulatory capabilities are not necessarily contracted. Indeed capable states learn how to increase their capabilities by governing through and with global institutions (Weiss, 2005: Levi-Faur, 2005).

\section{Conclusion}

Those who believe we are in an era of neoliberalism - where this means hollowing out of the state, privatisation and deregulation - are mistaken. The transitions since feudal structures of governance fell to incipient capitalist institutions have been from a Police Economy, to an Unregulable 19 $9^{\text {th }}$ Century Liberal Economy (that oscillated between laissez faire, dismantling the decentralized Police Economy and laying the bricks and mortar of an initially weak urban administrative state), to the Provider State Economy, to Regulatory Capitalism. Across all of these transitions, markets in fits and starts have tended to become progressively more vigorous, as has investment in the regulation of market externalities. Not only have markets, states, and state regulation become more formidable, so has non-state regulation by civil society, business, business associations, professions and international organizations. Separations of powers within polities have become more variegated, with more 
private-public hybridity. This means political science conceived narrowly as a discipline specialized in the study of public governance to the exclusion of corporate governance, NGO governance and the governance of transnational networks makes less sense than it once did. If we have entered an era of Regulatory Capitalism, regulation may be, in contrast, a fruitful topic around which to build intellectual communities and social science theory.

In seeing the separations among the periods posited in this essay, it is also important to grasp the posited continuities. Both markets and the state become stronger, enlarged in scope and transaction density, at every stage. The amount of governance in the world also continuously grows, because non-state forms of governance by firms, industry associations, NGOs and global institutions grow alongside growth in state governance capability. Elements of $18^{\text {th }}$ century police are retained in the creation of 19th century para-military police and other specialized regulators. Post-1980 Regulatory Capitalism learns from and builds upon the weaknesses (and the strengths) of $19^{\text {th }}$ and early 20th century regulation - from 21st century private security corporations learning from Peel's Met and the KGB, to state shipping regulators and the International Maritime Organization learning from regulatory technologies crafted in Lloyd's Coffee Shop. While many problems solved by state provision prior to 1980 are thence solved by privatisation into contested, regulated markets, most of the state provision of the era of the Provider State persists under Regulatory Capitalism. Even some re-nationalization of poorly conceived privatisation has begun.

While less welfare is state administered today and more is provided through contracted out, contested, regulated markets for welfare provision, state spending on welfare has not fallen. The rumours of the death of Keynes, and of Hayek's immortality, at the End of History were both exaggerated. Keynesian demand management is more complicated in the global economy, but remains 
a central preoccupation of Regulatory Capitalism. Hayek's insistence that central states lack sufficient local knowledge to plan investment underpins both the attraction of markets in regulatory capitalism and the attraction to devolved regulatory technologies that harness local knowledge (Shearing \& Wood 2003).

A fair criticism of this essay would be that its attack on the analytic value of neoliberalism as a package of privatisation, deregulation and rolling back the state assails a straw (wo)man. Milton Friedman agrees that privatisation is and should be combined with at least some kinds of regulation. No one implements the more radical prescriptions of the old Chicago School for abolishing antitrust. Those who point to the hollowing out of the state today mostly do so in a governance frame that notes its capacity to get things done through proliferating interdependencies, or in a Foucauldian frame that notes capacities to "govern at a distance" (Rose \& Miller 1992). Across all points of the political spectrum, there now seems as much concern about state failure as market failure, and about their interdependence. Perhaps that suggests there is some consensus around what Levi-Faur labels Regulatory Capitalism. Yet we have seen it is very limited. It follows that interesting agendas are Levi Faur's (2006) of documenting and comparatively dissecting the Varieties of Regulatory Capitalism, the Hall and Soskice (2001), Stiglitz (2002), Sachs (2005) and Rodrik (2005) agendas of diagnosing the institutional mixes that make capitalism buzz and collapse in the context of specific states, the Dorf and Sabel (1998) agenda of evidence-based "democratic experimentalism", the Campbell Collaboration and behavioural economics agendas for real policy experiments on the impacts of regulatory interventions (www.campbellcollaboration.org).

A contribution of this chapter has been to suggest that regulation, particularly antitrust and securitisation of national debt, enabled the growth of both provider and regulatory states. Regulation did this through pushing the spread of large corporations that made Chandler's $(1977,1990)$ three-pronged 
investment. The corporatisation of the world increased the efficacy of tax enforcement, funding provider and regulatory state growth. The corporatisation of the world drove a globalisation in which transnational networks, industry associations, professions, international organizations, NGOs, NGO/retailer hybrids like the Forest Stewardship Council, and most importantly corporations themselves (especially, but not limited to, stock exchanges, ratings agencies, the Big Four accounting firms, multinationals that specialize in doing states' regulation for them like Société Général de Surveillance, ${ }^{18}$ and large corporates that regulate small upstream and downstream firms in the same industry) became important national, regional and global regulators. This was a very different capitalism and a very different world of governance than existed in the early $20^{\text {th }}$ century industrial capitalism of family firms. Hence the power of Levi-Faur's conceptualisation of Regulatory Capitalism. While states are "decentred" under Regulatory Capitalism, the wealth capitalism generates means that states have more capacity both to provide and to regulate than ever before.

\footnotetext{
${ }^{18}$ This is a large Swiss multinational that provides all manner of regulatory services for states from environmental inspection to collecting nations' customs duties for them in innovative ways (Braithwaite \& Drahos 2000, 492-3).
} 


\section{References}

Ayres, Ian and John Braithwaite 1992. Responsive Regulation: Transcending the Deregulation Debate. New York: Oxford University Press.

Baldwin, R., Scott, C. and Hood, C. 1998. A Reader on Regulation. Oxford: Oxford University Press.

Beck, U. 1992. Risk Society: Towards a New Modernity. Beverly Hills: Sage.

Bevir, M. and Rhodes, R. 2003. Interpreting British Governance. London: Routledge.

Black, J. 2002. Critical reflections on regulation. Australian Journal of Legal Philosophy 27: 1-36.

Blackstone, W. 1966. Commentaries on the Laws of England, Vol 4. London; Dawsons.

Bourdieu, P. 1998.The essence of neoliberalism. Le Monde Diplomatique December: $1-6$.

Bradbury, N. 2002. Face the facts on transport safety. Railwatch. November: 6-7.

Braithwaite, J. 1985. To Punish or Persuade: Enforcement of Coal Mine Safety. Albany: State University of New York Press.

Braithwaite, J. 1994 The nursing home industry, in M. Tonry and A.J. Reiss (eds), Beyond the Law: Crime in Complex Organizations, Crime and Justice: A Review of Research 18: 11-54.

Braithwaite, J. 1997. On speaking softly and carrying sticks: neglected dimensions of republican separation of powers." University of Toronto Law Journal 47: 1-57.

Braithwaite, J. 2005. Markets in Vice, Markets in Virtue. Oxford and Federation Press: New York and Sydney.

Braithwaite, J., and Drahos, P. 2000. Global Business Regulation. Melbourne: Cambridge University Press.

Castells, M. 1996 The Information Age: Economy. Society and Culture, Volume 1: The Rise of The Network Society. Oxford: Blackwell. 
Castells, M. 2000 The Information Age: Economy. Society and Culture, Volume II1: End of Millenium. Oxford: Blackwell.

Castles, F. G. 2004. The Future of the Welfare State: Crisis Myths and Crisis Realities. Cambridge: Cambridge University Press.

Chandler, A. D. Jr. 1977 The Visible Hand: The Managerial Revolution in American Business. Cambridge, Mass.: Belknap Press.

Chandler, A. D. Jr. 1990. Scale and Scope: The Dynamics of Industrial Capitalism. Cambridge, Mass.: Belknap Press.

Chomsky, N. 1999. Profit Over People. New York: Seven Stories Press.

Clarke, M. 1986. Regulating the City: Competition, Scandal and Reform. Milton Keynes: Open University Press.

Coleman, J. S. 1982. The Asymmetric Society. Syracuse, NY: Syracuse University Press.

Cotterrell, R. 1999. Emile Durkheim: Law in a Moral Domain. Palo Alto: Stanford University Press.

Day, P. and Klein, R. 1987. Residential care for the elderly: a billion pound experiment in policy making." Public Money March: 19-24.

Dickson, P.G.M. 1993 The Financial Revolution in England: A Study in the Development of Public Credit, 1688-1756. Brookfield, VT: Gregg Revivals.

Dorf, M. and Sabel, C. 1998. A constitution of democratic experimentalism, Columbia Law Review, 98: 267-473.

Drahos, P. with Braithwaite, J. 2002. Information Feudalism. London: Earthscan.

Dudley, S. and Warren, M. 2005. Regulators' Budget Continues to Rise: An Analysis of the U.S. Budget for Fiscal Years 2004 and 2005. St. Louis: Weidenbaum Center, Washington University (http://wc.wustl.edu).

Durkheim, E. 1930. De la Division du Travail Social, 2nd ed. Paris: PUF.

Freeman, J. 2003. Extending public law norms through privatisation. Harvard Law Review 116: 1285-1291.

Freyer, T. 1992 Regulating Big Business Antitrust in Great Britain and America, 1880-1990. Cambridge: Cambridge University Press. 
Fukuyama, F. 1989. End of History. National Interest Summer:

Fukuyama, F. 2004. State-building: Governance and World Order in the 21st Century. Ithica: Cornell University Press.

Garland, D. 2001. The Culture of Control: Crime and Social Order in Contemporary Society. Oxford: Oxford University Press.

Grabosky, P.N. 1994. Green markets: Environmental regulation by the private sector. Law and Policy 16: 419-48.

Gunningham, N. and Grabosky, P. 1998. Smart Regulation: Designing Environmental Policy, Oxford: Clarendon Press.

Gurr, T.R., Grabosky, P.N. and Hula, R.C. 1977. The Politics of Crime and Conflict. Beverly Hills: Sage.

Hall, P.A. and Soskice, D. (eds.) 2001. Varieties of Capitalism: The Institutional Foundations of Comparative Advantage. Oxford: Oxford University Press.

Hannah, Leslie 1991. Mergers, cartels and concentration: legal factors in the US and European experience, in Giles H. Burgess, Jr. (ed) Antitrust and Regulation. Aldershot: Edward Elgar.

Harding, Richard W. 1997. Private Prisons and Public Accountability. Buckingham: Open University Press.

Hood, C., Scott, C., James, O., Jones, G.W. and Travers, A.J. 1999. Regulation Inside Government: Waste-Watchers, Quality Police and Sleaze-Busters. Oxford: Oxford University Press.

Israel, J. (1995) The Dutch Republic: Its Rise, Greatness and Fall, 1477-1806, Clarendon Press, Oxford.

Jayasuriya, K. 2001. Globalization and the changing architecture of the state: the politics of the regulatory state and the politics of negative co-ordination. Journal of European Public Policy 8(1): 101-23.

Johnston, L. and Shearing, C. 2003. Governing Security: Explorations in Policing and Justice. London: Routledge. 
Jordana, J. and Levi-Faur, D. (eds) 2004. The Politics of Regulation: Examining Regulatory Institutions and Instruments in the Governance Age. Cheltenham: Edward Elgar.

Jordana, J. and Levi-Faur, D 2003 The rise of the regulatory state in Latin America: A study of the diffusion of regulatory reforms across countries and sectors', Paper to the Annual Meeting of the American Political Science Association, August 28, 2003.

Levi-Faur, D. 2005. The global diffusion of regulatory capitalism. Annals of the American Academy of Political and Social Science.

Levi-Faur, D. (ed) 2006. "Varieties of regulatory capitalism." Forthcoming special issue of Governance.

Loughlin, M. and Scott, C. 1997. "The regulatory state." In Developments in British Politics 5, P. Dunlevy, I. Holliday and G. Peele (eds). London: Macmillan.

Macdonah, O. 1961. A Pattern of Government Growth: The Passenger Acts and Their Enforcement. London: Macgibbon and Kee.

McCraw, T.K. 1984. Prophets of Regulation. Cambridge: Harvard University Press.

Majone, G. 1994. "The rise of the regulatory state in Europe", West European Politics 17: 77-101.

March, J.G. and Olsen, J.P. 1995. Democratic Governance. New York: Free Press.

Markus, M. M. 2002. The New Regulatory State in Germany. Birmingham: Birmingham University Press.

Midwinter, A. and McGarvey, N. 2001. "In search of the regulatory state: evidence from Scotland." Public Administration 79(4): 825-49.

Moffet, J., Bregha, F. and Middelkoop, M.J. 2004. Responsible care: a case study of a voluntary environmental initiative. Pp 177-208 in Voluntary Codes: Private Governance, the Public Interest and Innovation, ed. K. Webb. Carleton, Canada: Carleton Research Unit on Innovation, Science and Environment. 
Montesquieu, C.de Secondat 1989 The Spirit of the Laws. Trans, and ed. A.M. Cohler and B.C. Miller. Cambridge: Cambridge University Press.

Moran, Michael 2003 The British Regulatory State: High modernism and HyperInnovation. Oxford: Oxford University Press.

Neocleous, M. 1998. Policing and pin-making: Adam Smith, Police and the State of Prosperity. Policing and Society 8:

Nussbaum, M. 1995. Human capabilities: female human beings." In Women, Culture, and Development, edited by M.C. Nussbaum and J. Glover. Oxford: Clarendon Press.

Osborne, D. and T. Gaebler. 1992. Reinventing Government: How the Entrepreneurial Spirit is Transforming the Public Sector. Reading, Mass: Addison-Wesley.

Parker, C. 1999. Just Lawyers. Oxford: Oxford University Press.

Parker, C. 2002. The Open Corporation. Melbourne : Cambridge University Press.

Pasquino, P. 1991. Theatrum politicum: the genealogy of capital - Police and the state of prosperity. in The Foucault Effect: Studies in Governmentality. ed. G. Burchell, C. Gordon and P. Miller. Hemel Hempstead: Harvester Wheatsheaf.

Peters, M. 1999. Neoliberalism. Encyclopaedia of Philosophy of Education (www.vusst.hr/ENCYCLOPAEDIA/neoliberalism.htm)

Polanyi, K. 1957. The Great Transformation. Boston: Beacon Press.

Power, M. 1997. The Audit Society: Rituals of Verification. Oxford: Oxford University Press.

Ramo, J.C. 2004. The Beijing Consensus. London: The Foreign Policy Centre.

Rees, J. 1994. Hostages of Each Other: The Transformation of Nuclear Safety Since Three Mile Island, Chicago and London: University of Chicago Press.

Rhodes, R. 1997. Understanding Governance. Buckingham and Philadelphia: Open University Press.

Rose, N. and Miller, P. 1992. Political power beyond the state: Problematics of government. British Journal of Sociology 43(2): 173-205. 
Rosoff, S.E., Pontell, H.N. and Tillman, R.H. 2002. Profit Without Honor: WhiteCollar Crime and the Looting of America. Upper Saddle River: Prentice-Hall. Schepel, H. 2005. The Constitution of Private Governance. Oxford: Hart.

Sen, A. 1992. Inequality Reexamined. Cambridge, MA: Harvard University Press. Shearing, C. and Wood, J 2003. Nodal governance, democracy and the new "denizens." Journal of Law and Society 30(3): 400-419.

Singer, P.W. 2002. Corporate warriors: The rise and ramifications of the privatised military industry. International Security 26

Smith, A. 1978. Lectures on Jurisprudence. Edited by R. L. Meek, D.D. Raphael and P. G. Stein. Oxford: Clarendon Press.

Smith, A. 1979. Inquiry into the Nature and Causes of the Wealth of Nations, ed. R. H. Campbell, A.S. Skinner and W.B. Todd. Indianapolis: Liberty Fund.

Stiglitz, J. E. 2002. Globalization and its discontents, W.W. Norton, New York.

Stiglitz, J.E. 2003. The ruin of Russia. Guardian, April 9.

Singer, P. W. 2002. Corporate warriors: the rise and ramifications of the privatized military industry. International Security, 26.

Tomlins, C.L. 1993. Law, Labor, and Ideology in the Early American Republic. New York: Cambridge University Press.

Tramontozzi, P.N. and Chilton, K.W. 1989. US Regulatory Agencies Under Reagan, 1960-1988. St. Louis, Missouri: Center for the Study of American Business, Washington University.

Vogel, Stephen K. 1996. Freer Markets, More Rules: Regulatory Reform in Advanced Industrial Societies. Ithica and London: Cornell University Press.

Wickerson, J., Reddon, N. and Khan, M 2001. Using Tax Return Data to Assess the 'Tax Performance' of Large Australian Companies: An 'Effective Tax Rate' Perspective, 1991/92 to 1997/98. In M. Walpole and C, Evans (eds.), Tax Administration in the $21^{\text {st }}$ Century. St Leonards, NSW: Prospect Media.

Yin, G. 2001. Getting serious about corporate tax shelters: Taking a lesson from history. Southern Methodist University Law Review 54: 209-237. 